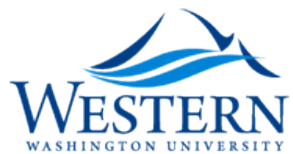

Western Washington University

Western CEDAR

2006

\title{
Nyama and Heka: African Concepts of the Word
}

Christopher Wise

Western Washington University, christopher.wise@wwu.edu

Follow this and additional works at: https://cedar.wwu.edu/english_facpubs

Part of the English Language and Literature Commons

\section{Recommended Citation}

Wise, Christopher, "Nyama and Heka: African Concepts of the Word" (2006). English Faculty and Staff Publications. 1. https://cedar.wwu.edu/english_facpubs/1

This Article is brought to you for free and open access by the English at Western CEDAR. It has been accepted for inclusion in English Faculty and Staff Publications by an authorized administrator of Western CEDAR. For more information, please contact westerncedar@wwu.edu. 


\section{NYAMA AND HEKA: \\ AFRICAN CONCEPTS OF THE WORD}

\section{Christopher Wise}

"Speech is not in people's hands. People are in the hands of speech." - a Mande proverb

\section{Introduction}

Knowledge of the West African griot epic has advanced enormously in the last fifteen years with the publication of volumes by Thomas Hale, Scribe, Griot, Novelist: Narrative Interpreters of the Songhay Empire ${ }^{1}$ and Griots and Griottes: Masters of Words and Music, ${ }^{2}$ Stephen Belcher, Epic Traditions of Africa; ${ }^{3}$ and Barbara G. Hoffman, Griots At War: Conflict, Conciliation, and Caste in Mande. ${ }^{4}$ Despite the richness of these studies, the concept of nyama, the Mande word for occult "power" or "means," has remained a secondary concern of African cultural criticism. Fascination with the figure of the griot has tended to overshadow the problem of nyama, or, in some cases, generic considerations have taken precedence over matters of the occult. In the first instance, the critic risks subordinating nyama to a Western idealism, or a Platonic logic, in the second, to an old-fashioned essentialism, or an Aristotelian logic. However, the extent to which nyama may be construed as a force generative of both complexes remains unarticulated. By assuming that nyama flows from the abysmal no-place of the blood-filled receptacle, and not the Platonic simulacrum of the human soul, many hitherto unresolved enigmas about the griot may be resolved. While it is true that the griot must "learn 
the secret of occult power [or nyama]," to quote John William Johnson, as is true of Sundiata Keita in the Mande Epic, ${ }^{5}$ knowledge of nyama-so that it does not destroy those who wield it-does not necessarily imply Cartesian mastery. I do not refer to a logocentric concept of nyama, but a psyche upon which the logos necessarily depends, a psyche that is blowing wind before it becomes mind. There can be no question of any new master term to anchor African cultural criticism. Instead, nyama must be construed as a word that may be replaced by any number of substitutions. If nyama is rethought as a properly Afrocentric complex, the most obvious candidate would be the Egyptian term heka [ in its place (assuming the hypotheses of Sigmund Freud and others that the great lawgiver hailed from Egypt), ${ }^{6}$ or-as Johnson proposes- the AfroIslamic "equivalent" of barakah might be synonymous with the Mande term nyama. ${ }^{7}$ There are plenty of terms that show the dispensability of the word nyama, including the Greek psyche before the Socratic invention of the soul. While the focus in this essay is on the Mande concept of nyama, and more generally the Mande world of the Bamana, ${ }^{8}$ Soninke, Khassonke, Maninka, and other groups, the argument being made here applies to the larger griot world made up of many other peoples in the region. For instance, equivalent Sahelian terms include the Soninke ñaxamala, the Wolof ñeeño, the Fulfulde nyeenyo, and the Toucouleur-Fulfulde nyaama.

It is difficult if not impossible to discuss the Mande term nyama without subordinating it to Greek metaphysics, a fact that necessarily complicateswithout vitiating - the "thesis" of my essay. After years of studying Songhay culture in Northern Niger, Paul Stoller makes a number of important discoveries about Sahelian conceptions of the word, but he ends by rejecting what he calls the "extreme" conclusions of his own research. Instead, Stoller opts for a "reconstruction of ethnography" based on the "imperfect debris" of phenomenology. ${ }^{9}$ In Griots at War, Hoffman observes that "there is no standard grammar or pronunciation [in Mande society] that underlies all others as a Chomskyan-style deep-structure, no monolithic 'competence' to which the analyst can make appeal." ${ }^{10}$ Hoffman nonetheless opts for a conventional ethnographic study of the griot's role in Mande society without pursuing the implications of her findings. Hoffman subordinates nyama to a humanist ethnography. The occult word is useful to both Stoller and Hoffman in revealing the truth of their respective ethnographic subjects. ${ }^{11}$ In his The Mande Blacksmiths, Patrick R. McNaughton also offers a thoughtful analysis of nyama in Mande society; ${ }^{12}$ however, by focusing exclusively on the blacksmith, his study runs the same risk as studies by scholars like Hale and Hoffman, which have focused on the griot but ignored others in Mande 
society who wield this power. The Mande who are called the nyamakala include griots [djelu], blacksmiths [numu], tanners [garanke], hunters [donzo], basket-weavers [fina], as well as Islamic praise-singers [funé]. To discuss griots apart from the context of their membership in this social group not only exaggerates their social significance, it also promotes a distorted image of the West African bard as a kind of folk troubadour.

Though the Mande concept of nyama seems to evoke the anti-humanism of post-structuralist theory, it is more closely akin to ancient ways of thinking about language that are African rather than deconstructive. The destrukion (or "de-sedimentation") of Platonic logocentrism could not have occurred without repositioning Socratic thought within the framework of Egyptian mythologies about language, particularly those surrounding the invention of writing by the god Thoth. ${ }^{13}$ In Egyptian theology, the creator god Ammon-Ra creates all other gods by an act of speech, or the breath of this god brings forth the universe. Ammon-Ra's oldest son is believed to be created by virtue of his 3 hw or "magic," but this occult power is also hypostatized as a god in its own right, the Egyptian god known as Heka [U] ] or the "Magician." “The word $h k_{3}$ is often left untranslated when it refers to the god: 'Heka;' or he is called: the god 'Magic,' Herman te Velde points out. "Besides magical power $h k$ $ə$ sometimes also means magical spell and magical rite." "14 Pneumatic exhalation (or "beka" [ infuses the world of things. "In the realm of Egyptian magic," Ogden Goelet comments, "actions did not necessarily speak louder than words. They were often one and the same... Thought, deed, image, and power are theoretically united in the concept of heka. The world is created with, through, by, and for speech." ${ }^{15}$ Memphite theology asserted that the universe was brought into being through the power of the spoken word. Throughout Egypt's long history, the breath remained at the center of Egyptian theology, an ancient concept of language that did not imply any bifurcation of invisible thought and unreal appearance. "In the cosmogony of Thebes," Cheikh Anta Diop notes, "the god Ammon will say: 'I am the God who became by himself, and who was not created." 16 Derrida observes that " $\mathrm{Ra}$ (the sun) is god the creator, and he engenders the mediation of the word. His other name, the one by which he is designated in [Plato's] Phaedrus, is Ammon." ${ }^{17}$ In Mande creation myth, the creator God is called Mangala (Ngala or Bemba by the Bamana), who creates the twin seeds fani berere and fani $b a$ from his eleusine seed. As is true in Egyptian creation myth, the seeds of Mangala are conceived in the "'egg of God' which is also called 'egg of the world." 18 "The world came out of an egg," as Derrida puts it. "The living creator of the life of the world came out of an egg... [I]n his capacity as origin of everything, 
Ammon-Ra is also the origin of the egg." ${ }^{19}$ The God of Genesis also speaks the world into being, but this ancient concept of language is repressed under Platonic-Christian hegemony. "[T]o assert that matter was not eternal, that the world had a temporal origin, that substance came into being through divine fiat, indeed through divine speech," Susan Handleman writes, "(And God said, "Let there be...") threatened the foundations of Greek ontology." ${ }^{20}$ In pre-Platonic Egyptian theology, the creator god brings forth the world through an act of speech but also by masturbating his children into existence. The spoken word and human semen are both construed as magical fluids that are voided from the god's body. The word is a seed, as is true in Platonic and Christian thought, but no womb or soul is required for its germination. The male god is self-sufficient, not a sower of seeds in search of fertile soil. His word or sperm is an autonomous and powerful force. $\mathrm{He}$ is the god who begets without partner and whose spirit infuses the world of things. There can be no objective universe for the god's word to reflect upon since it already saturates the realm of the ontological. In Egyptian theology, philosophy is breathtaking heresy, the True Ideal an unspeakable atheism. It is undeniable that Ammon-Ra's offspring Osiris is the father of the son Horus, but, like his Greek counterpart Zeus, Osiris remains the grandson of a more distant and originary father god. Osiris is the son of the son of the father god, who is himself not a metaphysical ground but a tortoise shell upon which the world is carried. The spectral abyss of fathers and sons marks a passage into eternity but guarantees nothing outside of its own emptiness. To quote Jan Assman, the creator god is "the one who makes himself millions... In Egyptian, 'millions' also means 'endless,' and the word is etymologically connected with the concept of 'eternity' as an endless plentitude of time." ${ }^{21}$ The paradoxical Greek belief in the Father as intangible yet "truly existing essence"-which is then represented by a filial copy in the unreal world of the senses-signifies a break from a far more ancient thinking of the word that flourished in Egypt and elsewhere, a theology of the word as groundless ground or mise en abime. Diop has convincingly shown Plato's indebtedness to Egyptian cosmogony, especially in the case of The Timeaus, a text that has also received much attention from Derrida and Julia Kristeva. In his last major work, Diop ponders the absence of an atheistic idealism in Egyptian thought, but this does not imply for him that Egyptian "philosophy" is somehow lacking in subtlety or sophistication. For Diop, the epistemological break of Platonism seems to be a sign of Athen's decadence rather than its strength. Diop's critique of Platonism mirrors those of Friedrich Nietzsche and Martin Heidegger. However, Nietzsche's critique of logical binarism in Western philosophy has been slow in entering 
into the mainstream of academic Egyptology. Tom Hare, who intervenes in the discipline of Egyptology as an outsider, is one of the few contemporary critics who has exhibited any awareness that Egyptian concepts of the word are merely different, not inferior to Greek ones: "[H]ow often have we heard that the Egyptians could not think abstractly, as the Greeks did," Hare observes. "This contention [...] confuses the presence of one thing with the absence of another." ${ }^{22}$ Western scholars of nyamakala have understandably been fascinated with the figure of the griot, but they have also-like their counterparts in Egyptology - not fully assimilated the lessons of Nietzsche, Heidegger, and Derrida. One notable exception may be McNaughton. In his wonderfully written The Mande Blacksmiths and elsewhere, McNaughton cautions about the problems inherent in projecting Greco-Christian ethics upon Mande culture: "A pattern runs through our literature on Mande culture that applies a Western sense of morality to ideas and practices that Mande individuals generally view in a different way." ${ }^{23}$ Father Joseph Henry's L'âme d'un peuple africain: Les Bambara, ${ }^{24}$ which was published in 1910, is perhaps the most obvious example of the ethnographic tendency to refract Mande society through the distorting lens of a Greco-Christian ethics. The concept of nyama has yet to fully recover from Henry's influential but misleading descriptions of it as a kind of Satanic fluid.

\section{Nyama, Heka, and Psychē}

The occult concepts of beka [ misconstrued as early variants of the post-Socratic Greek term Logos. In fact, heka [ $[\cup 1$ ] ruah, and nyama are closer to the Greek term psychē, which is a creative wind that intertwines with eros to birth the human soul. The OED defines psyche as meaning "breath, to breathe, to blow, (later) to cool; hence, life (identified with or indicated by the breath); the animating principle in man and other living beings, the source of all vital activities, rational or irrational, the soul or spirit, in distinction from its material vehicle, the body; sometimes considered as capable of persisting in a disembodied state after separation from the body at death." Martin Bernal suggests that the Egyptian root $s w$ [ $Q$ ] with the masculine article $k$ s may well be the origin of the Greek $p s y c b \bar{e} .^{25}$ The Egyptian article $k$ 3, also transcribed as $k a$, (or with the hieroglyph [U]), signifies the double, specter, or ghost. In Bernal's scheme, $k a$ is the etymological precursor of the Greek ker or kar in Dorian and Aeolic dialects (transcribed in Greek and Coptic as ke, ki, 
and $(h \circ i)$, which is used by Homer to mean "fate" or "soul." Bernal argues that the Greek term psyche e, in Egyptian $k_{3}$ [U] and $s w$ [ 4 ], represents "two different souls or aspects of the personality." ${ }^{26}$ Bernal's etymology of the Greek psyche $\bar{e}$ is convincing; however, the Egyptian $\check{s} w$ [ 4 ] is also a hieroglyph for invisible breath that is weighed against the heart of the dead man. For ancient Egyptians, admission to the afterlife is contingent upon speaking the truthful word. The spoken word is an invisible word. It may not be seen, hence the appropriateness of the sign of the feather, an object that is associated with weightlessness, or that may be blown by the mouth's wind. Bernal observes that $k$, which is signified by the hieroglyph for open arms [U], suggests a concept of "open relations between beings," ${ }^{7}$ but he does not comment upon the question of iterability in relation to the Egyptian concept of the double, or how words are meaningful only on the condition that they are repeated. Every Egyptian word has its ghostly double, but this does not mean that $k \ni$ is a metaphysical ground. In the Coptic New Testament, heka [ $[\cup]$ is used to signify the Greek word mageia or magic: "There are several words in the Egyptian language, including $3 h w$ and $h k_{3}$, which are usually translated as 'magic," te Velde notes. "The word $h k_{3}$ has been preserved in Coptic [...] and is found, int.al., in the Coptic bible translation of Acts 8, where it is used of the sorceries of Simon Magnus." ${ }^{28}$ Heka [ $\cup$ ], which is written as $H k_{3}$, signifies "magic power, divine creative energy [...] vital potential, [and] mysterious efficacy." ${ }^{29}$ Bernal's linking of the Egyptian $k$ з of $H k_{3}$ and the Greek $k \bar{e} r$ (or $k \bar{a} r$ ) of $p s y c h \bar{e}$ may be brilliant scholarship, but his theses regarding Egyptian philosophy are somewhat simplistic. In his zeal to restore Egypt's place in Western cultural history, Bernal ignores important differences between Sophist conceptions of the word and more abstract, atheistic, or philosophical conceptions. Whether or not Plato imports philosophy from Egypt, the Socratic articulation of logocentric thinking in The Phaedrus constitutes a significant break from the contingency based thinking of Sophists like Isocrates and Gorgias. PreSocratic thinkers in Greece are much closer to early Memphite theologians than Plato. Bernal may be correct that logocentric philosophy originates in Egypt, but it does not necessarily follow that radically different ways of thinking about language did not once prevail in Egypt, as they do now in West Africa. Bernal seeks to restore dignity to the ancient Egyptians by granting them the ability to think in philosophical terms; however, it never occurs to him that philosophical thinking may be a marker of Egypt's decline, not its greatness. ${ }^{30}$ In the Phaedrus, the hallucinatory receptacle of the Greek soul is not born until aspirated breath conjoins with sexual desire, or what Nietzsche calls a certain "musical mood." 31 The logos, which is inscribed on 
the soul, and which becomes the ground of truth in Platonism, represses the memory of the blood-filled lungs. A veil is drawn upon the bloody cavern from which the wet word blows. The deconstructive maxim that "there is no outside of the text" affirms the power of the word, spirit, or pneumatic wind; or, textuality always means spiritus. There is no outside of this occult power, no world of things for words (or "the Logos") to reflect upon. In other words, spirit or aspirated breath ushers forth from the cavern of the lungs, spurred on by orgiastic desire for union with the other. The pneumatic and the erotic intertwine to birth the soul as a hollowed out space that is outside the abyss of the blood-filled lungs, which are synonymous with heart. The soul or mind is born from spirit, from the groundless ground of the body although it buries the memory of its origin. Derrida's deconstruction of Platonic thought shows that the soul remains a myth of language, an invention of the spirit that is propelled by sexual longing for the other. The simulacrum that is called the Soul makes the radically impossible claim that it is "outside the text;" which is to say, outside the spirit of the mother. The Soul is a thing made of wind, after "the demonic secret of Eros has been put to work." ${ }^{2}$ There is no soul that is not first a matter of aspirated breath, which comes from the abyss of the blood-filled heart. We may say then that the soul or $p s y c h \bar{e}$ is a liquid text, not an interior receptacle but an exterior fluid that is ejaculated from the orifice of the human mouth. The Greek word psyche is a figure of speech, or an already impossible time-space conflation in which spirit (or aspirated breath) and specter (or the visual double) are conjoined in a paradoxical binary. This is so because the word that is heard by the ears can never be seen by human eyes, only its effect upon the body; conversely, the word that enters the body through the lens of the eyes can never be heard or spoken to, only silently observed. The Greek $p s y c h \bar{e}$ after Plato becomes a spirit-specter binary, a curtain now drawn over the abysmal coil of blood.

In Dissemination, Derrida describes the pharmakon as a powerful liquid that can disable or heal those who receive it. "[T] he pharmakon always penetrates like a liquid; it is absorbed, drunk, introduced into the inside [...] Liquid is the element of the pharmakon." ${ }_{33}$ The written word is associated with the pharmakon because it is disembodied or authorless, an orphan without a guardian to keep it from going astray. Plato would have us believe that the spoken word (or "spirit") is superior to the written word (or "specter") because of the presence of the good son, who represents the father in the false realm of the sensual. Heka [ written word) without a guardian, a spoken word that is always illegitimate, open-ended, and patricidal. In the case of nyama, the category of play is not stigmatized, as in the "disembodied" pharmakon of writing in the Phaedrus, 
but construed as a valorized and serious - if not deadly—activity. Hoffman emphasizes that in Mande society "polysemy is the norm and ambiguity is often the desired result: multiplicities of meanings are conveyed by Mande speech, often more meanings than we have English words for." ${ }^{34}$ In her $\mathrm{Ph} . \mathrm{D}$. dissertation, she observes that "[v]eracity is not the point of the jeliw's praise. They intend their words to stir, to move, to arouse strong emotions, to evoke that which is possible, not to describe that which is verifiable." 35 Hoffman also cites the Mande proverb "play does not kill seriousness," ${ }^{36}$ a folk aphorism that could not be further from the Socratic stigmatization of play in the Phadreus. In fact, Hoffman's Griots At War shows how lethal "play" can be in the Mande society. "It was through the process of studying the words of the naraw in Kita," Hoffman states, "that I learned how dangerous, even deadly, the nyama of talk can be. ${ }^{37} \mathrm{McNaughton}$ similarly insists that, for the Mande, "the interpretation of good and evil is much more dependent upon points of view." ${ }^{38} \mathrm{McNaughton}$ argues that "issues of good and evil seem rarely to drive the Mande." ${ }^{39}$ The simplest definition of nyama is "power" or "means," often repeated synonyms that reinforce a concept of language that is indifferent to ethics or ideal paternal authorities. If this is so, or if the Mande concept of nyama is closer to the Egyptian beka [U] ] than the post-Socratic Logos, it may be possible to rethink the role of the griot as a complex of nyama rather than a verbal artist who manipulates the material substance of language. Hoffman, for instance, describes nyama as "the energy that inhabits all matter and all beings." ${ }^{40}$ McNaughton, whose description Hoffman enthusiastically affirms, describes nyama as "the world's basic energy, the energy that animates the universe [...] a special energy or occult power." ${ }^{41}$ Scholars who have attempted etymologies of the Mande terms nyama and nyamakala have emphasized their complex history and ambiguity, their possible links to Soninké dialects and Western Mande forms of the word like nyakamala (nyaka for "celebration" and mala which means "to preserve"). In "Etymologies of Nyamakala," Charles S. Bird, Martha B. Kendall, and Kalilou Tera report that a well-known Malian jali-muso informed them that a defining criteria of the nyamakala is the ability to manifest majigi, the Mande word for "magic." ${ }^{2}$ The Egyptian word beka [ $[\cup]$ is the etymological precursor of the Greek mageia, or magic. ${ }^{43}$ Bernal shows how the Egyptian beka [U [ ] i the probable origin of the Greek word for hundred, which is hekaton, but also the old crone goddess of magic Hekate. ${ }^{44}$ Bernal's suggestion that beka [UU ] is the etymon of the Greek numeral hekaton is compelling in part because it implies a connection with the measuring scale of the jackal Annubis. What all of these terms share is the common root $k a[U]$ from the Egyptian beka 
[U ] which may be the etymological antecedent of the Greek psychē. Bird, Kendall, and Tera write that "[i]n a typical example, nyama is held to mean 'natural force' and kala is held to mean 'stick,' 'twig,' or 'straw' and, by extension, 'the handle of a tool,' as in dabakala, 'hoe handle."'45 The griot is someone who "know[s] how to handle nyama, as one would handle a tool."46 Bird, Kendall, and Tera also note that "the compound nyamakala [is] the only word in any Mande language in which kala refers to human agents." ${ }^{47}$ This later point is important because it dramatizes the unusual social status of the nyamakala, and also helps to account for the ancient custom of burying griots in baobab trees. The branch, twig, stalk, stick, or tool-handle suggest the penis, which ejaculates the seed from which the world springs; that is, kala's phallic connotations imply that nyama is semen that is ejaculated into the ear of the other. Citing her teacher El Hadji Yamuru Diabaté, Hoffman writes: "To speak griot language to someone is to make its nyama enter him." Bird, Kendall, and Tera list meanings for nyama as follows: "evil or satanic; morally neutral; dangerous; polluting: energizing or animating; necessary for action; or indicative of imperfect self-control." ${ }^{39}$ Nyama can also mean filth, waste, garbage, or refuse. McNaughton suggests that the root nya should be translated as "means [...] ability, the capacity to suceed, the wherewithal to make something work. " ${ }^{\circ 0}$ Youssouf Cissé also describes nyama as meaning life, spirit, or endowed with animated spirit, "a flux that obeys the will of the soul." ${ }^{51}$ The word is construed as a seed although Socrates dogmatically rejects disembodied forms of discourse as a pharmakon, a Greek word which means both "remedy" and "poison," as Derrida has shown. ${ }^{52}$ Bird, Kendall, and Tera document that "kala can mean 'powerful agent,' something with the force to kill, and, by extension, 'antidote' or 'remedy." 53 These scholars state, "This [meaning] expands the logical possible meanings for nyamakala to such things as antidote for evil; remedy against pollution; antidote for poison; or remedy for garbage. ${ }^{54}$ Nyama is not an illness, but it is a pharmakon that may cure or cause illness. The griot has historically been associated with tasks involving poison, including the poisoning of arrow tips. ${ }^{55}$ The nyamakala not only use their knowledge of poisons for the sake of warfare: they are also known as "masters of the leaves" or "masters of medicine [furatigiw]." ${ }^{56}$ David Conrad and Barbara Frank have suggested that griots may not be buried in the earth because of their connection to dangerous medicines: "[Informants] explain that if griots had been buried in the ground or thrown into the river or ocean, the crops would have failed or the fish would have died." 57

Though Father Henry conflates the nyamakala with Eurocentric satanism cults, he rightly emphasizes that the fluid of nyama may cause illness, suffering, and death. ${ }^{58} \mathrm{Te}$ Velde points out that the Egyptian concept heka 
[ $\{\cup$ ] similarly may be employed for evil purposes: "The Egyptians were aware that unordered creative energy was also at work [in the universe]," te Velde notes. "Sometimes we read of evil $h k \jmath$ or the need of protecting oneself against the h.k 3 of others." 59 Dominique Zahan remarks that "a skilled griot can derange or stupefy the one who hears his balemani [genealogy] recited, if he should not stop him in time with a gift." ${ }^{60}$ Occult possession is one possible consequence of the release of the fluid called nyama. "Nyama is a force, a power," Henry writes, "or if one prefers, an energy, a fluid possessed by every man, every animal, every living being." ${ }^{61}$ Henry rightly insists upon the matter of fluid in his definition, as does Charles Monteil, who calls nyama "a fluid common to all nature." ${ }^{2}$ Nyama can also mean the saliva that is necessary to hold the wind together as well as a magical substance with healing properties. Johnson reports seeing a Mande woman asking a griot for a blessing by holding out her hands so that he could spit into them. The woman then "bathed" in the spittle by rubbing the liquid blessing into her face: "In Mali incantations over various libations are generally terminated by spitting into the mixture before it is consumed," Johnson comments. "The moisture of the spittle vitalizes the power of the brew." ${ }^{63}$ In fact, the saliva of the griot, because it is infused with nyama, is believed to possess curative properties ${ }^{64}$ West African views about the supernatural aspects of the griot's saliva are echoed in numerous Egyptian texts such as The Egyptian Book of the Dead: The Book of Going Forth By Day. "Spittle has an important function in a number of Egyptian creation stories where a generative force akin to that of semen is ascribed to it," Goelet notes. ${ }^{65}$ In The Egyptian Book of the Dead, spittle is characterized as possessing curative powers (see Chapters 17, 72, and 102). The liquid substance of mother's blood, transmuted into a bonding saliva, is yet another manifestation of the Mande word, provided we think it outside the categories of the ontological. "The text is spit out," Derrida comments, "It is like a discourse in which the unities model themselves after an excrement, a secretion. And because it has to do here with a glottic gesture, the tongue working on itself, saliva is the element which sticks the unities together." ${ }^{\prime 66}$ In this sense, saliva, blood, sweat, urine, feces, and semen are interchangeable.

\section{Nyama and The Body's Fluids}

In a physiological sense, the elocutionary utterance comes from the blood filled lungs as a wet wind that penetrates the ear of the other. The ancient 
Egyptians imagined the word's interior site as a container of blood, or heart filled with the blood of the mother. In The Papyrus of Ani, this text's most famous image depicts the heart of the mother as it is weighed on the scale of judgment against the feather of truth [ $\check{s} w]$ or [ 4 ], the hieroglyph for invisible breath. The occult word is a wind that drips with the blood of the mother. The word comes from this bloody no-place as a powerful force. Blood is the essence of pneumatic breath, but it is not a metaphysical substance. The word of the nyamakala is saturated with the blood of the other. Sory Camara has argued that links between the Mande terms for griot and blood are purely coincidental, proposing instead that the term jeli or djeli (the Mande term for griot) may come from the Mande word for "housing," which is jiyali, from the verb jiya, which means "to house a person." ${ }^{\prime 7}$ However, there is an important link between the terms jeli (the Mande word for blood) and jiyali (the Mande word for housing), rather than a nullifying contradiction, as Camara suggests. This is so because the dwelling that is the "groundless ground" or site of spirit's origin is an earth-cavern, maternal womb, or house made of blood. After surveying all known tales of the nyamakala's origins, Hale concludes that "[b]lood [...] appears as a common feature of all of these stories of [the griot's] origin and reinforces the close association between the griot and a significant social taboo." ${ }^{68}$ West African legends of the "first" griot involve an act of cannibalism during which an older brother cuts off a piece of his flesh to feed his starving younger sibling. Hale points out that the wide diffusion of the tale of the two brothers, one of whom unwittingly commits an act of cannibalism, offers evidence of the ancientness of this story ${ }^{69}$ For instance, Claude Meillassoux has recorded a medieval Soninké version of the griot's origin that recounts the fall of the Ghana Empire. ${ }^{70}$ The similarities between this ancient legend of the griot's origin and the religious enactment of Egyptian ritual are striking. Ritual performances of the Osirian monomyth, which were staged throughout the Nile Valley for centuries, pitted Seth against Horus, or Osiris's killer and brother against his posthumously conceived son. ${ }^{71}$ In one of the cycle's most often repeated episodes, Horus tricks Seth into eating his semen, which is disguised in lettuce. "The loser is the one who is penetrated by the semen of the other," Jan Assman notes. ${ }^{72}$ After unwittingly eating Horus's semen, Seth must acknowledge that Horus is more powerful, and that he is now subject to Horus. In fact, Seth must publically proclaim that Horus is the rightful ruler: "The triumph of Horus signifies the end of strife and the beginning of a period of peace and well being," Assman comments, "a period to which every king laid claim." 73 The Osiris cycle reenacts the reconciliation of Upper and Lower Egypt, but it also establishes the protocol of noble and the 
one who must publicly sing his praises. When Seth and the "first" griot eat semen or blood, they violate a primal taboo by inverting the natural order. They make themselves monstrous by performing an act that leads to their downfall and creates a clearly defined social hierarchy. Both Seth and the griot are tricked into performing an act that they feel is profoundly abhorrent. If this act is performed unwittingly, it also empowers the griot in far-ranging ways. In the Egyptian context, te Velde points out that "an ordinary person would certainly like to make magic or to be creative, but he is only rarely able to do so." 74 The violation of the taboo against consuming the body's fluid converts the ordinary person into an extraordinary one. This taboo is referenced in The Book of the Dead which contains numerous chapters that are formulas uttered to prevent the eating of human feces: "What I detest, I will not eat" the scribe Ani repeatedly swears. ${ }^{75}$ In a fascinating etymology of nyamakala, the Malian scholar Bokar N'Diaye writes that nyama means manure, filth, or feces. ${ }^{76}$ N'Diaye's etymology of nyama as feces is also affirmed by Meillassoux, who reports that popular Mande etymologies of this term emphasize its meaning as "ordure" [human waste]. ${ }^{77}$ Nyama is then all of these things: blood, semen, feces, saliva, the strange and powerful substances of the human body. Nyama not only means energy or life force, it also means "feces, trash, garbage, and, by extension, bloated, swollen," $\mathrm{McNaughton}$ states, "literally crawling with nature's products or processes gone out of control." ${ }^{78} \mathrm{McNaughton's} \mathrm{etymology} \mathrm{coordinates} \mathrm{very} \mathrm{well}$ with Stoller's personal experience of occult power as "the filth [that is] in the heart." "The apparent continguity between power and filth implies the danger harbored by the power. The world's energy allowed to get out of hand could leave the world a fetid ruin." ${ }^{80}$ In the Christian scriptures, it is precisely the ancient injunction against eating human feces that Jesus of Nazareth calls into question: "It is not what enters one's mouth that defiles that person; but what comes out of the mouth is what defiles one," Jesus insists. "Do you not realize that everything that enters into the mouth passes into the stomach and is expelled into the latrine?" (Matthew 15:11-17). Like the Christian god-man, the nyamakala become outcasts because they have violated the taboo against eating the body's waste. Hale summarizes a wide range of scholarly sources to suggest that griots are buried in baobab trees because they are polluted by their consumption of the body's fluids and are therefore considered unworthy of burial in the earth. ${ }^{81}$ 


\section{Nyama, Gender, and The Musical Instrument}

If the breath or spirit also implies a bodily fluid, the significance of the bard's instrument may be linked to its ability to generate this powerful substance. One of Susan and Roderick McIntoshes' more dramatic finds at Jenne-Jeno includes a stone fetish of a reclining figure wearing an amulet around its neck. ${ }^{82}$ The figure, as the McIntoshes note, is clearly hermaphroditic; the fact that it wears an amulet around its neck arguably links it to the griots, who to this day arm themselves with amulets in a similar manner. ${ }^{83}$ By definition, the griot is the one who defies conventional binaries: "Despised yet desired, needed yet loathed," Hoffman writes. "Nowhere is this paradox thoroughly explicated; however, where there is social paradox, there are usually questions of power at issue." ${ }^{84}$ Matters of gender identity are finally subordinate to nyama, as well as the sheer power of erotic desire. The power of the breath in Mande society is inextricable from the music of the instrument, which awakens orgiastic desire. A. M. Jones has written about what he calls "African metrical lyrics," or the inseparability of music and lyrics in the Sahelian context. ${ }^{85}$ The music of the ngoni, kora, balafon, and drum necessarily intertwines with the aspirated breath of the griot. (It is important to point out that the ngoni, molo, and related instruments are far more common than the kora as the primary stringed instruments for the griot.) The musical instrument functions chiefly as an aphrodisiac to coax pneumen from the lungs. To insist upon the indispensability of the kora is really to insist upon the indispensability of sexual desire, for the griot cannot sing until he or she is sufficiently aroused by the music. In regards to the drum, Titinga Frederic Pacéré is probably right to suggest that the word of the drum, what he calls "bendrology" [bendre More for "drum made from a calabash" +logy or word] is in some sense "prior" to both the oral-aural word and the music of the stringed instrument, but only insofar as he means the invisible rhythm of the blood-filled heart. This word could not, however, be a metaphysical "Logos" but a physiological organ that pumps blood. In fact, the Moré word for griot also is "bendre," as Pacéré himself points out: "The Bend-Naba, or chief of the Bendré (drum made from a calabash), is the chief of the griots." ${ }^{\prime 66}$ The actual or external drum, like the kora, ngoni, or balafon, is also an aphrodisiac to get the griot's heart beating, or to heat up the blood of the griot.

The instrument of the griots and the musicians of ancient Egypt serve a similar function despite apparent gender differences of the performers. Eric Charry and Hale have been cautious about articulating possible links 
between the Egyptian lute and its West African counterpart [in Mande the ngoni; in Wolof, xalam; in Fulbe, hoddu; in Soninké, gambare; in Songhay molo]. Charry, for instance, argues that the linguistic evidence is sketchy, emphasizing that the Egyptian lute was played by women, not men. ${ }^{87} \mathrm{It}$ is true that Egyptian images of the lute depict women rather than men playing this instrument, but the performer's gender is either irrelevant or secondary to the question of beka [ $\quad$ ] or the magical wind that issues from the throat. In numerous images of the Egyptian goddess Hathor, she is shown bestowing a pearl necklace called a menat upon her lover. The menat is not only an ornament worn around the neck, but a musical instrument that inaugurates the resurrection of the dead. Isis similarly brings Osiris from the dead through her healing sexual powers. The sistrum, or sesheshet, which is like a rattle or gourd, serves a similar function: to transmit vital energy to her lover that is necessary to his spiritual rebirth. Hathor, mistress of the menat, is "the female element that puts into motion the intrinsic forces of all manifestations of the divine. ${ }^{" 88}$ The ngoni similarly stirs the griot's desire so that nyama may be ejaculated from his throat: what the Greeks called "eros" is indispensable to this process. This is why the lyrics and the music are "inseparable," as Jones puts it. If women alone are depicted playing the lute in the Egyptian pyramid texts, Hare points out that in Egyptian art more generally " $[t]$ he objects of erotic attention seem to be exclusively women." ${ }^{89}$ Charry is correct that only women are depicted playing the lute in ancient Egypt, but it is likely that these images merely signify the sexism of the artisan. "There is, obviously, a close relationship between the economic structure of the funery industry [in ancient Egypt] and the construction of the epistemological subject," Hare states. "[T]ombs and their accoutrements were overwhelmingly created for men [...] As a consequence, the epistemological position upon which these artifacts are centered is male." ${ }^{90}$ In regards to the concept of beka [lบ what is more significant is the Egyptian conception of the instrument as aphrodisiac.

\section{Nyama and the Apparition of the Inapparent}

The concepts of nyama and beka [ [U imply an occult materialism of the body, which is nonetheless not a metaphysics. The Mande see nyama "as both natural and mystical," McNaughton states, "a special energy or occult power which most Westerners would consider supernatural." ${ }^{11}$ Ironically, occult articulations of the word end by returning language to the body without 
affirming the human subject in any originary sense. But this also means that the world of the griot is a frightening world of spirit without presence, a world where ghosts are real and "man" is the chief ghost of all. In research I conducted among the Umarian Tidjaniya of Northern Mali and Burkina Faso in 1996-1997 (a Sufi brotherhood mainly comprised of Toucouleur Fulani and Dogon adepts), I was surprised to find that Toucouleur-Fulani and Dogon adepts believed that images of the dead could be summoned from a collective archive through the occult power of certain sounds. In fact, this power was credited to the teaching of the ancient Egyptians, should the ones who utter them be sufficiently pure of heart. ${ }^{92}$ Mohamed Abdoulaye Maïga, whom I interviewed in Ouagadougou in August 1997, informed me of the following:

[T] here are certain sounds that exist, pure sounds that have been passed down through the centuries. These sounds have no real meaning in themselves. They are devoid of sense... You will find these sounds in the Quran, but they are much older than the time of Muhammad. They originate before the founding of Christianity, even Judaism. The Egyptians taught these sounds to the Jews, who passed them down in their turn... If uttered by the person disciplined in Islam, one may evoke images of the dead, even conversing with the dead... God loves all people the same, of course, but those who follow his commandments receive higher favors. If such a person utters these sounds, he can gain access to the archive wherein the totality of human history resides. This archive contains everything that has ever happened and that will happen in history, the past as well as the future... Everyone who has ever lived or who will ever live also exists within this archive. I mean their psychic bodies, of course, our doubles. Not our physical bodies. ${ }^{93}$

The elocutionary word for the ears (or "spirit" in deconstructive thought) is not identical to the signatory word for the eyes (or "specter" also in deconstructive thought). The spoken word is an invisible wind that blows over the fine hairs of the ears. When the double appears, it is a spectral image generated by the power of the breath, in Toucouleur-Fulfulde nyaama. The specter can be seen, or so the conspirators believe, but it is not present in any ontological sense. The Umarian Tidjaniya adepts conjure the apparition through the power of the voice, a ritual in which the son becomes the father of the father. The conjurer births the image that wells up from within himself. Although the thing that he sees cannot be seen, for vocal- 
ized wind (or "spirit") is not figurative image (or "specter"), he must accept on faith this impossible event, the appearance of the ghostly simulacrum. Those who allegedly see the specter swear to keep silent, thereby affirming their role as authoritative guardians of the "archive" from which the specter is summoned, the maternal house of blood. The archive (from the Greek arkbe) "names at once the commencement and the commandment" Derrida observes, "the order of the sequential, or the there where things commence" and "the order of the jussive, or the there where men and gods command." 94 However, a veil is always drawn upon the maternal dwelling or earth cavern and its secrets, which may not be disclosed on penalty of death. There is no theology, no possibility of belief, without the secret. The specter or mbeelu (in Fulfulde) may or may not appear: "One will never be able to prove that it happened," Derrida observes, "but only swear that it did." ${ }^{95}$ It is always possible that faith in the specter's apparition, or the appearance of the invisible ghost, amounts to simple conspiracy. It is certain, in any event, that those who forcibly remove the veil are destined to find nothing, for there is nothing behind the sound. Maïga's description of Umarian Tidjaniya conjuration rites emphasizes the importance of sound apart from semantic meaning. The sound uttered by Sufi adepts is not wholly without meaning though its meaning seems to reside in the tone: "These words have no real meaning in themselves," Maigga insists, but are "pure sounds. ${ }^{" 96}$ The concept of a "pure sound" is paradoxical; however, Maigga's description resonates with the findings of Sahelian researchers like Judith T. Irvine, Stoller, $\mathrm{Pa}$ céré, Hoffman, and others. Stoller insists that, for the Songhay, "[sound] is believed to have an existence separate from the domains of human, animal, and plant life." "Sounds carry forces which are not only good to think, but good to feel." "Z Zahan similarly describes nyama as a kind of "vibration" that can be felt from deep inside the body. ${ }^{99}$ Irvine, whom Stoller cites from an unpublished paper, also argues that words in West Africa "do not just have meaning." 100 Among the Wolof people, Irvine suggests, "[words] are breath and vibrations of air, constituted and shaped by the body and motives of the speaker, physically contracting and influencing the addressee." For this reason, Irvine compares the "effects of a griot's praise song to the effects of wind upon fire (both metaphorically and literally, since air and fire are supposed to be basic constituents of the body)." Irvine's views are echoed by Hoffman, who points out that the manner of speaking may be more important in the Mande context than the actual words themselves: "We may choose our words, but we cannot control how they are understood, or what effects they have once they are spoken," Hoffman states. "What cannot be communicated by the word itself, it is hoped, will be transmitted by the way the 
word is spoken, by the context in which it is used, by the expressiveness with which it is uttered." 101 Stoller also argues that the occult word in the Sahel should be defined as as "an energy which should be apprehended in and of itself rather than only as a representation of something." 102 Maïga's description of the word as "pure sound" is anti-Platonic, but he also affirms his belief in the iterability of these ritually transmitted sounds. The Umarian Tidjaniya's emphasis on the integrity of those who utter them insures that the adept's repetition of the pure sound will not entail a mechanical parody of it, but an authentic enactment, a true affirmation. The meaning of the sound lies not only in its esoteric tone, but the religious belief or enunciation of the speaker. The sound must be felt as a vibration from deep inside the body, as a physiological trembling of the entrails.

\section{Conclusion}

Recent anthropological and cultural critics of the nyamakala have tended to refrain from interpreting gathered data about nyama, instead contenting themselves with an objective presentation of the facts. Given the vast cultural differences that must be negotiated between the West and the Sahel, this would seem an eminently safe route. However, the unadorned display of evidence rests upon the guileless appeal to Logos. According to Aristotle, reason is irrefutable brute fact that always trumps personal authority, as well as the audience's empathy for the matter at hand. To better appreciate the Sahelian context, it may be worth remembering that the Western Logos is already an ethos, an "ethics" behind which sits the dwarf of certainty. There is no speaking of nyama that is not already a theory of nyama. At present, North American and European scholarship on the griot seems to have reached an impasse, hamstrung by the inherent ethnocentrism of its critical methodologies. Deconstruction cannot in itself deliver the occult secrets of African concepts of the word like beka [U] and nyama, but it can circumvent the more obvious limitations of post-Socratic philosophy. Its success, in this regard, lies less in its novelty as literary theory than its lack of novelty, the fact that it echoes forgotten ways of thinking about language that prevailed before the Platonic "error of truth" was first articulated. 


\section{Notes}

1. Thomas Hale, Scribe, Griot, Novelist: Narrative Interpreters of the Songhay Empire. (Gainesville: U of Florida $\mathrm{P}, 1990$ ).

2. Thomas Hale, Griots and Griottes: Masters of Words and Music. (Bloomington: Indiana UP, 1998).

3. Stephen Belcher, Epic Traditions of Africa. (Bloomington, Indiana: Indiana UP, 1999).

4. Barbara G. Hoffman, Griots At War: Conflict, Conciliation, and Caste in Mande. (Bloomington: Indiana UP, 2001).

5. John William Johnson,"Introduction," The Epic of Son-Jara: A West African Tradition. (Bloomington: Indiana UP, 1992) 9.

6. Sigmund Freud, Moses and Monotheism. (New York: Vintage, 1939). Also, see Jan Assman, Moses the Egyptian: The Memory of Egypt in Western Monotheism. (Cambridge: Harvard UP, 1997).

7. Johnson, 9.

8. Although the French use "Bambara" and the term has wide usage, American Mande specialists prefer "Bamana" as a term that more accurately reflects what this people calls itself. I will use the term "Bamana" here, except in cases of usage in formal article titles and original citations.

9. Paul Stoller, The Taste of Ethnographic Things: The Senses in Anthropology. (Philadelphia: U of Pennsylvania P, 1989) 139-140.

10. Hoffman, Griots At War 19.

11. In a footnote on the griot-novelist Massa Makan Diabaté, Hoffman describes Diabaté as a man "who felt himself trapped between the two worlds of orality and literacy and who was deeply conflicted about his griot identity" (265). The Platonic speaking-writing binary is so dramatically emphasized that one can only wonder if Hoffman does not project her own dilemma upon Diabaté.

12. Patrick R. McNaughton, The Mande Blacksmiths: Knowledge, Power, and Art in West Africa (Bloomington: Indiana UP, 1988).

13. See Jacques Derrida, Dissemination (Chicago: U of Chicago P, 1981) 75-94.

14. Herman te Velde, "The God Heka in Egyptian Theology," Jaarbericht van het Voorsaiatishch-Egyptisch Genootshap. Ex Oriente Lux, Vol. 21 (1970) 177.

15. Ogden Goelet, "A Commentary," The Egyptian Book of the Dead: The Book of Going Forth By Day, trans. Raymond Faulkner (San Francisco: Chronicle Books, 1998) 145-146.

16. Cheikh Anta Diop, Civilization or Barbarism (Chicago: Lawrence Hill Books, 1991) 329.

17. Derrida, Dissemination 87.

18. Germaine Dieterlen, “The Mande Creation Myth," Africa, Vol. 27 (1957) 126.

19. Derrida, Dissemination 87.

20. Susan A. Handelman, The Slayers of Moses: The Emergence of Rabbinic Interpretation in Modern Literary Theory (Albany: State U of New York, 1982) 27; original emphasis.

21. Jan Assman, The Search For God in Ancient Egypt. Ithaca \& London: Cornell UP, 2001) 240.

22. Tom Hare, Remembering Osiris: Number, Gender, and the Word in Ancient Egyptian Representational Systems (Stanford: Stanford UP, 1999) 279.

23. Patrick R. McNaughton, "The Semantics of Jugu: Blacksmiths, Lore, and 'Who's Bad' in Mande," Status and Identity in West Africa: Nyamakalaw of Mande, ed. David C. Conrad and Barbara E. Frank (Bloomington: Indiana UP, 1955) 46.

24. Joseph Henry, L'âme d'un peuple african: Les Bambara, leur vie psychique, éthique, sociale, religieuse (Munster: Aschendorff, 1910).

25. Martin Bernal, Black Athena: The Afroasiatic Roots of Classical Civilization, Volume II: The Archaeological and Documentary Evidence (New Brunswick: Rutgers UP, 1991) 264-265.

26. Bernal, Black Athena, Vol. II 265.

27. Bernal, Black Athena, Vol. II 264. 
28. Te Velde, 176.

29. Te Velde, 186.

30. Martin Bernal, Black Athena: The Afroasiatic Roots of Classical Civilization, Volume 1: The Fabrication of Ancient Greece, 1785-1985 (New Brunswick: Rutgers UP, 1987) 140-141.

31. Friedrich Nietzsche, The Birth of Tragedy (New York: Anchor Books, 1956) 37.

32. Jacques Derrida, The Gift of Death (Chicago \& London: U of Chicago P, 1995) 12.

33. Derrida, Dissemination 152.

34. Hoffman, Griots At War 19.

35. Barbara G. Hoffman, The Power of Speech: Language and Social Status among Mande Griots and Nobles, Ph.D. dissertation, (Indiana University, 1990) 80.

36. Hoffman, The Power of Speech 6.

37. Hoffman, Griots At War 37.

38. McNaughton, "The Semantics of jugu" 51.

39. McNaughton, "The Semantics of jugu" 51.

40. Hoffman, Griots At War 67.

41. McNaughton, The Mande Blacksmiths 15.

42. Charles Bird, Martha B. Kendall, and Kalilou Tera, "Etymologies of Nyamakala," Status and Identity in West Africa, ed. David C. Conrad and Barbara E. Frank (Bloomington and Indianapolis: Indiana UP, 1995) 31.

43. Te Velde, 186.

44. Bernal Black Athena Vol II 484.

45. Bird et al, 28.

46. Bird et al, 28.

47. Bird et al, 28.

48. Barbara G. Hoffman, "Power, Structure, and Mande jeliw," Status and Identity in West Africa, ed. David C. Conrad \& Barbara E. Frank (Bloomington \& Indianapolis: Indiana UP, 1995) 43.

49. Bird et al, 28.

50. McNaughton, "The Semantics of jugu" 51.

51. Youssouf Cissé, "Notes sur les sociétés de chasseurs Malinké," Journal de la Société des Africanistes, Vol. 34, No. 2 (1964) 193.

52. Derrida, Dissemination 94.

53. Bird et al, 29.

54. Bird et al, 29.

55. David Conrad and Barbara E. Frank, "Nyamakala; Contradiction and Ambiguity in Mande Society," Status and Identity in West Africa, ed. David C. Conrad and Barbara E. Frank (Bloomington and Indianapolis: Indiana UP, 1995) 6.

56. McNaughton, The Mande Blacksmiths 47.

57. Conrad and Frank, "Nyamakala" 6.

58. Henry, 27.

59. Te Velde, 185.

60. Dominique Zahan, La Dialectique du verbe chez les Bambara (Paris: Mouton \& Co, 1963) 141.

61. Henry, 27.

62. Charles Monteil, Les Bambara du Ségou et du Kaarta (Paris: Larouse, 1924; Reprint, Paris: G.P. Maisonneuve et Larouse, 1976) 121.

63. Johnson, 124.

64. Hoffman, Griots At War 169.

65. Goelet, 147.

66. Jacques Derrida, Of Grammatology (Baltimore: Johns Hopkins UP, 1976) 161.

67. Sory Camara, Gens de la parole: Essai sur la condition et le rôle des griots dans la société malinké (Paris: Mouton, 1976) 101.

68. Hale, Griots and Griottes 64.

69. Hale, Griots and Griottes 62. 
70. Claude Meillassoux, "Histoire et institutions du kafo de Bamako d'après la traditions des Niaré," Cabiers d'Etudes Africaines, Vol. 4, No. 14 (1964) 189-190.

71. Assman, The Search For God 124.

72. Assman, The Search For God 140.

73. Assman, The Search For God 141.

74. Te Velde, 185.

75. Te Velde, 134.

76. Bokar N'Diaye, Les castes au Mali (Bamako: Editions Populaires, 1970) 14.

77. Meillassoux, 79.

78. McNaughton, The Mande Blacksmiths 18.

79. Paul Stoller, In Sorcery's Shadow (Chicago: U of Chicago P, 1989) 127.

80. McNaughton, The Mande Blacksmiths 18.

81. Hale, Griots and Griottes 194-196.

82. Roderick McIntosh and Susan Keech McIntosh, "Finding West Africa's Oldest City," National Geographic, Vol. 162, No. 3 (September 1982) 415.

83. Hoffman, Griots At War 37.

84. Hoffman, Griots At War 12.

85. A.M. Jones, "African Metrical Lyrics," African Language Studies, Vol. 5 (1964) 52-53.

86. Titinga Frédéric Pacéré "Saglego, or Drum Poem (for the Sahel)," The Desert Shore: Literatures of the Sahel, ed. Christopher Wise. (London \& Boulder: Lynne Rienner Publishers, 2001) 64.

87. Eric Charry, "Plucked Lutes in West Africa: An Historical Overview," Galpin Society Journal (March 1996) 17-18.

88. Ruth Schumann Antelme and Stephane Rossini, Sacred Sexuality in Ancient Egypt (Rochester: Inner Traditions, 2001) 47.

89. Hare, 139.

90. Hare, 138.

91. McNaughton, The Mande Blacksmiths 15.

92. The unusual nature of Sahelian conjuration rites led me to mistakenly assume that these practices were specific to this region. During the 2001-2003 academic years, however, I conducted further research among Sufi brotherhoods in the Occupied Territories (or Palestine) and Jordan and found that the beliefs of the Umarian Tidjaniya are by no means specific to West Africa. In one case, a prominent professor of the Shari'a faculty at the University of Jordan, Amman was known to talk to spirits during his lectures (although, like Yambo Ouologuem, he was locally viewed as an eccentric).

93. Christopher Wise, "Yambo Ouologuem Among The Tidjaniya," Yambo Ouologuem: Postcolonial Writer, Islamic Militant (Boulder, Colorado: Lynne Rienner Publishers, 1999) 228.

94. Jacques Derrida, Archive Fever (Chicago: U of Chicago P, 1995) 1; original emphasis.

95. Jacques Derrida, Veils (Stanford, California: Stanford UP, 2001) 83-84.

96. Wise, 228.

97. Stoller, The Taste of Ethnographic Things 112.

98. Stoller, The Taste of Ethnographic Things 112.

99. Zahan, 133.

100. Stoller, The Taste of Ethnographic Things 112.

101. Hoffman, Griots At War 33-34.

102. Stoller, The Taste of Ethnographic Things 117; emphasis mine. 